\title{
DOES SUPPORTING EMPLOYEES' CAREER ADAPTABILITY LEAD TO COMMITMENT, TURNOVER, OR BOTH?
}

\section{Jack K. Ito and Céleste M. Brotheridge}

Today, employees are encouraged to become more career-resilient and engage in career development activities to deal with changes in required knowledge, skills, and abilities, and to facilitate their mobility. This study found that participation in decision making (PDM) and autonomy, along with supervisory career support (information, advice, and encouragement), fostered this career adaptability. These practices were also positively associated with commitment and negatively with intentions to leave. However, career adaptability was positively associated with both commitment and intentions to leave, suggesting some unintended consequences for management approaches supporting career adaptability. Implications for research and practice are discussed. (C) 2005 Wiley Periodicals, Inc.

Developing workforce flexibility is a central organizational strategy in pursuing innovation, adaptation, and efficiency. To meet changing needs for knowledge, skills, and abilities (KSAs), organizations may develop employees under the umbrella of employment security or they may use market mechanisms such as hiring and disengagement, defined-term contracts, and outsourcing. Although growing organizations may employ both strategies, the trend toward the latter at the expense of the former has eroded the notion of the long-term career and altered the corresponding psychological contract with employees (Brockner, 1992; Tsui, Pearce, Porter, \& Hite, 1995). Today, careers once thought to be secure, including those within the professional, technical, and managerial classifications, are at risk (Sullivan, 1999). To manage this risk, employees are being encouraged to increase their career adaptability through a combination of career resilience (London, 1983, 1993), development activities, and networking. Career adaptability enhances employability within and outside an organization (Arthur, 1994; Ellig, 1998; Hall, 1996; London, 1983, 1993; Waterman Jr., Waterman, \& Collard, 1994). Moreover, supervisors are being encouraged to support employee development through actions such as providing career advice (London \& Smither, 1999). The resulting changes in KSAs enables organizations to meet their changing needs while retaining organizationally specific knowledge (Roehling, Cavanaugh, Moynihan, \& Boswell, 2000). It

Correspondence to: Jack Ito, Faculty of Administration, University of Regina, Regina, Saskatchewan, Canada, S4S 0A2, 306-585-4714, jack.ito@uregina.ca

Human Resource Management, Spring 2005, Vol. 44, No. 1, Pp. 5-19

(c) 2005 Wiley Periodicals, Inc. Published online in Wiley InterScience (www.interscience.wiley.com). DOI: $10.1002 / \mathrm{hrm} .20037$ 
This study examines the extent to which this catch-22 situation actually exists-i.e., the extent to which these work practices are more likely to result in an intention to leave the organization rather than increased affective commitment. also enhances employees' confidence that their investments will be rewarded.

An emerging dilemma is that actions undertaken to build commitment as a means of motivating and retaining valued employees also may increase employees' opportunities for employment in other organizations (Cappelli, 1999). To meet this challenge, organizations attempt to provide satisfying work contexts that competing employers find difficult to replicate (Cappelli, 1999). These work contexts include high-involvement practices such as participation in decision making (PDM) and encouragement of autonomy or discretion in task performance (e.g., Lawler, 1986). These practices and supervisory support for career development help employees meet their needs for personal growth through self-development and continuous learning (London \& Smither, 1999) and, as a result, build affective commitment (Meyer, Stanley, Herscovitch, \& Topolnytsky, 2002). Affective commitment is associated with reduced voluntary turnover, which enables organizations to retain the organizationally specific knowledge necessary for competitive advantage. However, these work practices enhance employees' career adaptability and employability, which, in turn, may increase voluntary turnover. This presents human resource practitioners with a catch-22 situation: advocating involvement, career resilience, and career development may build commitment and workforce flexibility, but also may inadvertently contribute to the departure of valued employees. Although the possibility that the new employment contract characterized by building personal security through employability results in voluntary turnover has been proposed (e.g., Pfeffer, 1998; Waterman et al., 1994), there is a lack of empirical research that addresses this issue.

This study examines the extent to which this catch-22 situation actually exists-i.e., the extent to which these work practices are more likely to result in an intention to leave the organization rather than increased affective commitment. This study builds on existing research that supports the relationships among attractive work contexts, affective commitment, and voluntary turnover. It also addresses a gap in the literature regarding the role of high-involvement practices such as PDM and autonomy and supervisory support of employee development in enhancing employees' career adaptability and its implications for commitment and turnover intentions. In this article, we propose and test an integrative model that addresses this gap.

\section{Workforce Flexibility and Risk}

Workforce flexibility is based on developing or hiring employees with the KSAs needed to meet changing organizational requirements. If these KSAs are organizationally specific and are primarily developed over time and experience, an internal labor market system (ILM) will meet these requirements. The human resource policies supporting this model include employment security, internal transfers and promotions, and employee training and development (i.e., building rather than buying needed KSAs). An external labor market strategy tends to be employed when positions require general professional or technical knowledge combined with organizationally specific knowledge that is easily learned. This strategy relies on practices such as subcontracting and definedterm contracts, as well as a pattern of hiring and layoffs as a means of managing changing knowledge and skill requirements (i.e., buying needed KSAs on a just-in-time basis). The related human resource policies include limited job security, external hiring at various hierarchical levels, and limited training and development (Doeringer, 1967).

To meet an accelerating demand for product and service innovation, the introduction of new technologies, and efficiency goals, many organizations are setting aside employment security policies associated with the ILM in favor of external market-oriented strategies. These strategies use an economic perspective, for example, comparing retraining costs to the costs of external staffing when introducing new technologies. This approach is consistent with the belief that traditional concepts of loyalty should be displaced in favor of recognizing economic realities (McKendall \& Margulis, 1995). As a result, employees face an increased risk in 
terms of a potential loss of jobs, demotions, and other uncertainties such as the number and nature of future available positions (Brockner, 1992; Feldman, 1996). To manage this risk, employees may enhance their career adaptability and, therefore, their employability within and outside the organization (Arthur, 1994; Waterman et al., 1994). In short, security resides not in the implicit contract between employee and employer but rather in employees' ability to adapt to change and take advantage of opportunities (Roehling et al., 2000). However, such employee adaptability may result in increased voluntary turnover as employees become more qualified for, seek, and accept employment opportunities in other organizations (Stroh, Brett, \& Reilly, 1994). Thus, although career adaptability reduces risks for employees, it also may heighten the risk that employers will lose their investments in employee KSAs traditionally recouped in the ILM.

A second type of career risk that employees face is whether their returns (such as promotions, salary gains, and security) will justify investments in KSAs and organizational contributions. In order to accurately assess this risk, employees must understand the pattern of investments that will be valued in the future. A related concern is whether the organization will fully recognize one's investments, since some will be tacit and otherwise difficult to measure. In ILMs, this risk is mitigated since employees have time to alter their patterns of investment to fit organizational needs, and organizations have time to support development efforts and reverse errors (e.g., to promote previously plateaued employees). However, in today's environment, the time available to make such adjustments is more limited, and much of the cost of error is borne by employees. Career advice and support of development activities signal which investments are likely to be realized and, thus, mitigate this risk. The preceding discussion suggests the importance of further understanding the causes and consequences of career adaptability and providing career direction and development, as these processes address two key risks employees face in these economic times.

\section{Model and Hypotheses}

The proposed model indicates that PDM, autonomy, and supervisory career support enhance both career adaptability and affective commitment, which, in turn, are positively and causally related but have opposite effects on turnover intentions (see Figure 1). The model also posits that career adaptability decreases employees' dependence on their employers and that such dependence reduces levels of voluntary turnover. The following discussion develops the hypotheses linking the variables to each other. Because of the complexity of the model, the common approach of developing the narrative from the independent to the dependent variables is reversed. The first section consists of defining dependence, affective commitment, and turnover intentions and relating these to each other. The second section develops the relationships between career adaptability and the variables in the first section. Finally, PDM, autonomy, and supervisory support are related to career adaptability, affective commitment, and turnover intentions. This order of presentation begins with well-established relationships and, by defining the right-hand variables first, enables a more focused discussion of the causal relationships.

\section{Affective Commitment and Turnover Intentions}

An employee's intention to leave an organization, expressed in such terms as making plans to search for a new job, reflects the potential for voluntary turnover. The significant affect-based predictors of voluntary turnover include job dissatisfaction (e.g., Hom \& Kinicki, 2001; Trevor, 2001) and affective commitment, a psychological attachment expressed as pride in the organization and a willingness to exert extra effort (e.g., Cohen, 1993; Lee \& Mowday, 1987; Mathieu \& Zajac, 1990; Meyer et al., 2002). A more recent perspective has considered the episodic nature of voluntary turnover, including employees exploring and accepting other opportunities as part of a career plan (Lee \& Mitchell, 1994; Lee, Mitchell, Wise, \& Fireman, 1996). ...security resides not in the implicit contract between employee and employer but rather in employees' ability to adapt to change and take advantage of opportunities. 


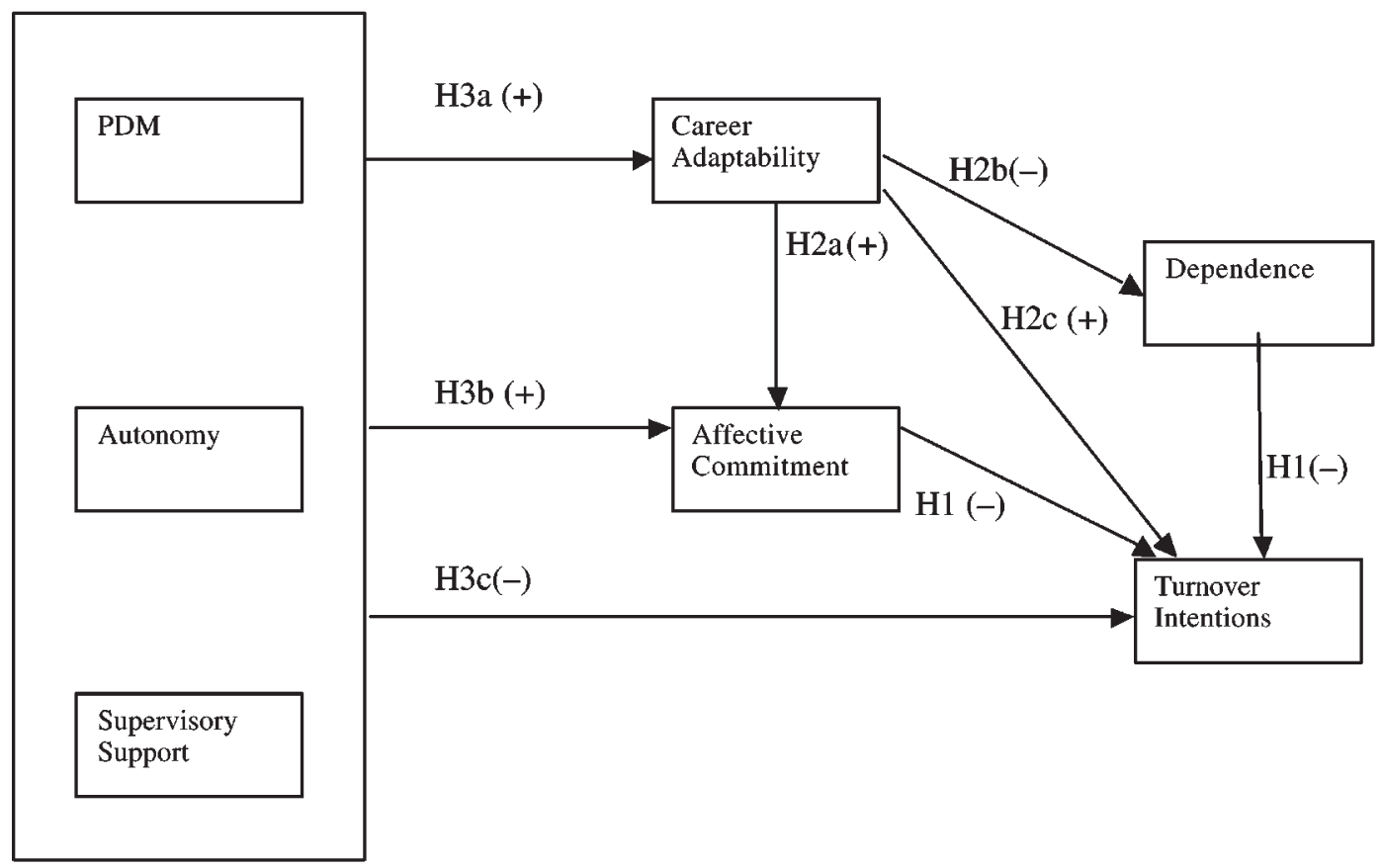

The model being tested has a path from each of PDM, autonomy, and supervisory support to each of career adaptability, affective commitment, and turnover intentions.

Figure 1. Theoretical Model.

Continuance commitment is another form of an individual's attachment to the organization, an aspect of which is one's dependence on the organization for employment and career progress (Carson, Carson \& Bedian, 1995; Meyer \& Allen, 1984; Meyer, Allen \& Smith, 1993). Dependence is associated with investments in organizationally specific knowledge, such as techniques, networks, and cultural adaptations, not readily transferable to other organizations. In the logic of the ILM, these investments grow over time and increase dependence (e.g., Doeringer, 1967) and, by limiting opportunities, inhibit voluntary turnover. The little research evidence on the dependence-voluntary turnover relationship is mixed but generally supportive (Allen \& Meyer, 1996), while the linkage is weaker than for the affective commitment-voluntary turnover association (Jaros, 1997; Meyer et al., 2002).

Hypothesis 1: Affective commitment and dependence are negatively associated with turnover intentions.
Career Adaptability, Dependence, Affective Commitment, and Turnover Intentions

The central variable in this article, career adaptability, is composed of two separate but conceptually and empirically related factors: career development activities that develop resources to manage job transitions and career resiliency or attitudes toward change (London, 1983, 1993). Career development activities facilitate mobility and adaptation and, thus, are an integral part of developing a boundaryless career pattern (Arthur, Claman, \& DeFillippi, 1995; DeFillippi \& Arthur, 1994). They include formal and informal training and development programs, cross-functional and lateral movements, and temporary assignments to broaden KSAs. Although some activities enhance general and organizationally specific professional and technical knowledge, others build more subtle resources such as unique personal competencies and the ability to synthesize complex information (Weick \& Berlinger, 1989). 
Activities that build general competencies facilitate transitions across boundaries. For example, developing interpersonal competence and group decision-making skills facilitates socialization into new work units, and skills in building networks enhance visibility and access to other positions.

Career resilience represents an ability to adapt to changes in work circumstances, including an openness to change, a willingness to take risks, and confidence in handling problems (London, 1983). Employees high in career resilience are more willing and able to accept job transitions that entail the possibility of failure (Latack, Kinicki, \& Prussia, 1995). Career development activities and career resilience are expected to mutually influence each other in a positive manner. Career-resilient people are likely to engage in self-development activities that will enable them to take advantage of opportunities (London \& Smither, 1999). And success in managing role changes, aided by development activities, is likely to reinforce career resilience. Moreover, retrospective rationality, that behaviors and decisions (development activities) influence perceptions about personal characteristics (resilience) (London, 1983), suggests that developing personal resources that help to cope with job changes will reinforce career resilience.

Exchange theory provides a rationale for linking career adaptability to affective commitment (Adams, 1963, 1965; Eisenberger, Huntington, Hutchison, \& Sowa, 1986; Whitener \& Walz, 1993). Although proactive career development requires individual initiatives, organizations play a significant role by providing resources, including training and development opportunities and job assignments that meet career objectives, as well as feelings of personal growth. For example, Wayne, Shore, and Liden (1997) found that corporate training and assignment to challenging jobs and projects served to build important skills and were associated with perceptions of positive organizational support. This support was linked to affective commitment.

Since career adaptability increases mobility and the willingness to take advantage of opportunities, we expect it to be negatively associated with perceptions of dependence on the organization for employment (dependence is not synonymous with career adaptability, since individuals may seek mobility within the organization). Although empirical support is limited, a variable related to career adaptability, perceived transferability of skills and education, is negatively associated with dependence (Meyer et al., 2002).

The foregoing suggests:

Hypotheses $2 a$ and 2b: Career adaptability is (a) positively associated with affective commitment and (b) negatively associated with dependence.

The foregoing implies that career adaptability indirectly increases intended turnover through dependence (Hypothesis 1). However, since employability is a future-oriented concept and speaks to the potential generation of attractive employment alternatives and adaptation to changes in the labor market, it also should directly increase intended turnover. Therefore:

Hypothesis 2c: Career adaptability is positively associated with turnover intentions.

Participation in Decision Making, Autonomy, and Supervisory Support

Whereas PDM engages employees in decision making as part of a team or in their interactions with their supervisor, autonomy refers to the exercise of individual discretion in day-to-day decision making. PDM helps employees develop KSAs that are organizationally specific (e.g., how things work around here) and general (e.g., the ability to work in teams). Both PDM and autonomy help employees build skills in identifying, assessing, and evaluating decisions, and may encourage employee initiative in, for example, modifying work processes, developing priorities, and allocating resources. These skills and abilities are among those identified as contributing to enhanced career resilience (London, 1993). PDM and autonomy also provide employees with opportunities to engage in career development activities, such as selecting tasks that fit a career plan and building personal net-
Career-resilient people are likely to engage in selfdevelopment activities that will enable them to take advantage of opportunities. And success in managing role changes, aided by development activities, is likely to reinforce career resilience. 
Exercising

influence (through PDM and autonomy) and supervisory support may encourage active career development and build career resilience. works through interactions with people in other units. And as an expression of collegiality and mutual influence, PDM and autonomy may help employees to develop and match their KSAs with organizationally valued activities (Karasek, 1979).

Practitioners and researchers have underscored the important role of supervisors in career development (e.g., London \& Smither, 1999). Supervisory support includes providing feedback on task performance and encouragement regarding career development. This support helps employees monitor their career progress and formulate and execute developmental activities consistent with their career plans. By providing information that facilitates predictability and control, supervisory support enhances career resilience (London, 1993; Noe, Noe, \& Bachhuber, 1990). Thus, exercising influence (through PDM and autonomy) and supervisory support may encourage active career development and build career resilience (e.g., Arthur, 1988). The foregoing discussion suggests that:

Hypothesis 3a: PDM, autonomy, and supervisory support are positively associated with career adaptability.

A substantial body of evidence supports the direct, positive relationship of PDM, autonomy, and supervisory support in career development with affective commitment (see Meyer et al., 2002). PDM and autonomy help employees meet their higher-order needs by exercising valued skills and knowledge and by influencing work-related decisions. The process of sharing influence and information their supervisors may serve to clarify path-goal relationships for employees (House \& Mitchell, 1974), facilitating meeting personal goals. Supervisory support may help employees meet their goals for continuous improvement and for becoming valued members of the organization.

Although the model suggests these processes influence voluntary turnover through affective commitment, there is reason to support a direct linkage to voluntary turnover. First, as suggested earlier, these are valued processes, and it is not certain they will be replicated in other organizations. For example, compatibility between one's preferences for engagement in decision making and the supervisor's leadership style should not be taken for granted. Second, supervisory support increases the likelihood the employee is allocating personal resources toward developing KSAs that will be valued in the future. Moreover, other organizations may not be able to provide assurances that investments already made will be rewarded in the future.

Hypotheses 3b and 3c: PDM, autonomy, and supervisory support are positively associated with affective commitment (H3b) and negatively associated with turnover intentions $(\mathrm{H} 3 \mathrm{c})$.

\section{Method}

\section{Participants}

Participants included 600 full-time employees in the prairie region of the Canadian federal civil service. The present study was part of a broader study that examined the issues of careers, stress, and change in the public service. A central career development unit supplied questionnaires to departmental contacts who, in turn, distributed the questionnaires to employees within their departments. Of the estimated 5,000 surveys distributed (the total number of employees in the region), 680 questionnaires were returned (a 12\% response rate). A comparison of the characteristics of the participants with those of potential respondents and with the Canadian federal civil service as a whole revealed the participants' characteristics were reasonably comparable with those of the comparison groups (data available from the first author). The male-female ratio of the respondents was 50/50 versus the 49.1/50.9 ratio for the regional distribution. Respondents, on average, were 43 years old $\left(\chi^{2}=\right.$ $.66,3$ df, N.S.). Respondents were relatively well-educated individuals, with about $41.7 \%$ having either an undergraduate or a graduate degree, and were experienced civil servants, with about $73 \%$ having worked for the federal government for at least eight years. The 
participants' reported income was similar to the national statistics (regional information was not available; $\chi^{2}=.65,3 \mathrm{df}$, N.S.). Participants included individuals employed in executive, scientific and professional, administrative and foreign service, technical, administrative support, and operational classifications. The occupational distribution of the participants was significantly different from that of the regional workforce $\left(\chi^{2}=\right.$ $12.4,5 \mathrm{df}, p<.05)$, with an overweighting in the scientific and professional category and an underweighting in the operational category. Thus, this sample has a higher percentage of white-collar workers than does the regional workforce.

\section{Measures}

Although the study employed several previously published measures, some measures were developed specifically for this study. As a result, exploratory factor analysis was followed by a confirmatory factor analysis to determine an appropriate measurement model for combining career resilience and career development activities. A five-point Likert scale was used for all measures in this study. An exploratory factor analysis, using varimax rotation, revealed seven factors, with few cross-loadings larger than .20 and factor loadings ranging from .68 to .86 .

PDM (4 items, $\alpha=.87$ ) and autonomy (3 items, $\alpha=.73)$ were measured with items drawn from Ito and Peterson (1986). Two sample items are: "How frequently do you participate in decisions about tasks being added or taken from your work unit?" and "The job gives me considerable opportunity for independence and freedom in how I do the work." London's (1983, 1993) measure of supervisory support ( 4 items, $\alpha=.84$ ) was adopted in this study. Sample items include: "Please rate the extent to which your supervisor provides you with ongoing feedback on your work performance" and "Please rate the extent to which your supervisor encourages you to develop in your current job.”

The measure of affective commitment (3 items, $\alpha=.84$ ) was employed by Reichel and Neumann (1993) and derived from Mowday, Steers, and Porter (1979). A sample item is:
"I really care about the fate of this organization." The measure of dependence was developed specifically for this study ( 3 items, $\alpha$ $=.58)$, but is similar to a measure developed by Meyer and Allen (1984) and McGee and Ford (1987). A sample item is: "It would be hard to find employment outside the department." This scale's modest alpha level may be a function of its small number of items (Bernardi, 1994; Cortina, 1993). Although this level of alpha does not approximate the standard .70 threshold, it may be considered acceptable given that this study is exploratory in nature (Hair, Anderson, Tatham, \& Black, 1995). Moreover, the items correlated more highly among themselves than with items for the other variables. However, it is lower than the alpha of .72 found by McGee and Ford (1987). Intention to leave was measured by two items $(\alpha=.72)$ that were developed by Fried, Tiegs, Naughton, and Ashforth (1996). A sample item is: "I am planning to search for a new job during the next 12 months."

The measures of career development activities ( 4 items, $\alpha=.80$ ) and career resilience ( 4 items, $\alpha=.80$ ) were both developed by London $(1983,1993)$. Sample items are: "Please rate the extent to which you are developing skills that may be needed in future career positions" and "To what extent are you able to adapt to changes," respectively. The original factor analysis revealed these as two separate factors, but with crossloadings. Since these are distinct but related constructs that mutually reinforce one another, we tested three alternative measurement models.

We used confirmatory factor analysis (Arbuckle \& Wothke, 1999) to test three measurement models corresponding to the approaches for conceptualizing relationships between career resilience and career development activities. In this article, the remaining variables are treated as latent, with the items as the indicators. Model 1 designated career adaptability as a latent variable with two latent variables, career development activities and career resilience, serving as its indicators. This model is consistent with career adaptability as a combination of career resilience and career development activities.
Compatibility between one's preferences for engagement in decision making and the supervisor's leadership style should not be taken for granted. 
The paths from dependence, affective commitment, and career adaptability to the intention to leave, and from career adaptability to affective commitment were all significant, supporting an interpretation that they are not spurious relationships.
Model 2 designated career adaptability as a latent variable with the career development and career resilience items as its indicators. Model 3 was a solution in which career development and career resilience were separate latent variables, with the corresponding items as the indicators. This model separates these variables that are conceptually reciprocally interdependent and are empirically highly correlated. We found that Models 1 and 3 were good fits to the data and were both significantly better fits than Model 2 (Model $1\left(\chi^{2}=646.4, \chi^{2} / \mathrm{df}=2.15 ; \mathrm{p}=.000\right.$; CFI $=.945$; RMSEA $=.045)$; Model $3\left(\chi^{2}=\right.$ $644.77, \chi^{2} / \mathrm{df}=2.18 ; p=.000 ; \mathrm{CFI}=.944$; RMSEA $=.045)$. However, Model 1 was more parsimonious and, thus, was accepted. If Model 3 were used, career resilience and career development activities would have been reciprocally related, and interpretation would have been extremely difficult. Overall, the results of the confirmatory factor analysis support the measurement model used in the study.

\section{Analysis}

AMOS Version 4.0 (Arbuckle \& Wothke, 1999) was used to evaluate the fit of the model with the data. Since the number of paths to be estimated relative to the sample size was large, single summary indicators of the constructs, rather than the individual items themselves, were employed. Adjustments were made for measurement error following Williams and Hazer (1986), based on Kenny (1979). In this approach, the path from the construct to the measured variable is the square root of the reliability (coefficient alpha) of the measured variable. The random error variance is 1 coefficient alpha. The few missing data were replaced with the mean score for the variable obtained from the rest of the sample, an approach consistent with Cohen and Cohen (1983) and Frone, Yardley, and Markel (1997). This approach has been employed in other studies with complex models (e.g., Frone, Russell, \& Cooper, 1992) and is supported by a study that found the substantive results of a latent variable model and a single indicator model to be equivalent (Netemeyer, Johnston, \& Burton, 1990).

The model in Figure 1 specifies a number of direct and indirect paths. For example, supervisory support (A) is expected to have a direct influence on the intention to leave $(\mathrm{C})$, but also an indirect influence since it influences affective commitment (B), which in turn influences the intention to leave (C) (here, $\mathrm{B}$ is an intervening variable). This results in two alternatives to the proposed model. In the first alternative, A influences both $\mathrm{B}$ and $\mathrm{C}$, with no direct relationship between B and C. That is, the observed relationship is spurious, due to the common association of both $\mathrm{B}$ and $\mathrm{C}$ with A. Following Whitener and Walz (1993), the test of this alternative involves setting the coefficient of the path between $\mathrm{B}$ and $\mathrm{C}$ to zero and comparing its goodness of fit with the proposed model. If the proposed model is not a significantly better fit than the alternative model, then B does not serve as an intervening variable.

In the second alternative (performed only if $B$ is shown to be an intervening variable), there is no direct influence-that is, B fully mediates the relationship between A and C. Following Holmbeck (1997), the test of this alternative sets the coefficient of the path between $\mathrm{A}$ and $\mathrm{C}$ to zero, and if the proposed model is not a significantly better fit than this alternative model, then A does not have a direct relationship with C. Since there are many direct and indirect paths in the proposed model, ten tests were completed, as shown in Table II.

To test the extent to which demographic variables would have influenced the important paths in the model, we entered demographic variables first in a stepwise multiple regression. These variables were seniority (measured by the number of years with the government), level of education, sex, age, personal (not household) income, and the number of people supervised. The results are presented in Table III.

\section{Results}

The means, standard deviations, and intercorrelations of the study variables are provided in Table I. As shown in Table II, the 
TABLE I Descriptive Statistics and Intercorrelations Among Study Variables $(\mathrm{N}=600)$

\begin{tabular}{|c|c|c|c|c|c|c|c|c|c|}
\hline & $M$ & $S D$ & 1 & 2 & 3 & 4 & 5 & 6 & 7 \\
\hline 1. PDM & 2.78 & .91 & & & & & & & \\
\hline 2. Autonomy & 3.57 & .75 & $.34^{* * *}$ & & & & & & \\
\hline 3. Supervisory support & 2.17 & .86 & $.33^{* * *}$ & $.24^{* * *}$ & & & & & \\
\hline 4. Career adaptability & 3.24 & .66 & $.23^{* * *}$ & $.12^{* *}$ & $.29 * * *$ & & & & \\
\hline 5. Fairness & 2.49 & .85 & $.22^{* * *}$ & $.26^{* * *}$ & $.43^{* * *}$ & .08 & & & \\
\hline 6. Dependence & 2.87 & .87 & $-.14^{* * *}$ & $-.10^{*}$ & $-.10^{*}$ & $-.25^{* * *}$ & $-.09 *$ & & \\
\hline 7. Affective commitment & 3.70 & .83 & $.31^{* * *}$ & $.36^{* * *}$ & $.26^{* * *}$ & $.21^{* * *}$ & $.36^{* * *}$ & $-.09^{*}$ & \\
\hline 8. Turnover intention & 2.47 & 1.30 & $-.08^{*}$ & $-.19 * * *$ & $-.15^{* * *}$ & $.17^{* * *}$ & $.28^{* * *}$ & $-.16^{* * *}$ & $-.33^{* * *}$ \\
\hline
\end{tabular}

${ }^{*} \mathrm{p}<.05 ;{ }^{* *} \mathrm{p}<.01 ;{ }^{* * *} \mathrm{p}<.001$

paths from dependence, affective commitment, and career adaptability to the intention to leave, and from career adaptability to affective commitment were all significant, supporting an interpretation that they are not spurious relationships. The remaining paths concerned whether affective commitment and career adaptability completely mediated the relationships of PDM, autonomy, and supervisory support to the intention to leave and whether career adaptability mediated the relationships of PDM, autonomy, and supervisory support to affective commitment. Of these, the autonomy to the intention to leave relationship was close to significance $(p=$ $.07)$, but the PDM to the intention to leave was not significant. The model with standardized regression coefficients is shown as Figure 2. As shown in Table III, the magnitudes of the regression coefficients are similar to those in the model (Figure 2), with one exception: the role of PDM in predicting career adaptability is lower once demographic characteristics are taken into account. The differences between the regression coefficients of Figure 2 and Table III reflect the

TABLE II Fit Indices of the Sequence of Alternative Models

(1) The path from variable to the intention to leave is set to zero.

\begin{tabular}{|c|c|c|c|c|c|c|}
\hline Variable & $d f$ & $\chi^{2} / d f$ & $p$ & CFI & $R M$ & $p$ diff \\
\hline Proposed model & 9 & 0.85 & .58 & 1.00 & .00 & \\
\hline Dependence & 10 & 1.45 & .15 & .99 & .03 & $* *$ \\
\hline Affective commitment & 10 & 7.38 & .00 & .90 & .10 & $* * *$ \\
\hline Career adaptability & 10 & 4.78 & .00 & .94 & .08 & $* * *$ \\
\hline \multicolumn{4}{|c|}{ (2) The path from career adaptability to affective commitment is set to zero. } & .99 & .03 & $*$ \\
\hline \multicolumn{7}{|c|}{ (3) The path from the variable to the intention to leave is set to zero. } \\
\hline Supervisor support & 10 & 2.38 & .01 & .98 & .05 & $* *$ \\
\hline Autonomy & 10 & 1.10 & .36 & .99 & .01 & .07 \\
\hline PDM & 10 & .76 & .66 & 1.00 & .00 & .85 \\
\hline \multicolumn{7}{|c|}{ (4) The path from the variable to affective commitment is set to zero. } \\
\hline Supervisor support & 10 & 1.29 & .23 & 1.00 & .02 & $*$ \\
\hline Autonomy & 10 & 5.08 & .00 & .94 & .08 & $* * *$ \\
\hline PDM & 10 & 1.83 & .05 & .99 & .04 & $* * *$ \\
\hline
\end{tabular}

${ }^{*} \mathrm{p}<.05,{ }^{* *} \mathrm{p}<.01,{ }^{* * *} \mathrm{p}<.001$.

$\chi^{2} / \mathrm{df}=\chi^{2} /$ degrees of freedom; $\mathrm{CFI}=$ comparative fit index; $\mathrm{RM}=$ root mean square of approximation; $\mathrm{p}$ diff is the difference between the proposed model and the alternative ones. A significant $\mathrm{p}$ diff indicates that the alternative model is a significantly poorer fit than the proposed model — that is, the omitted path is significant. 


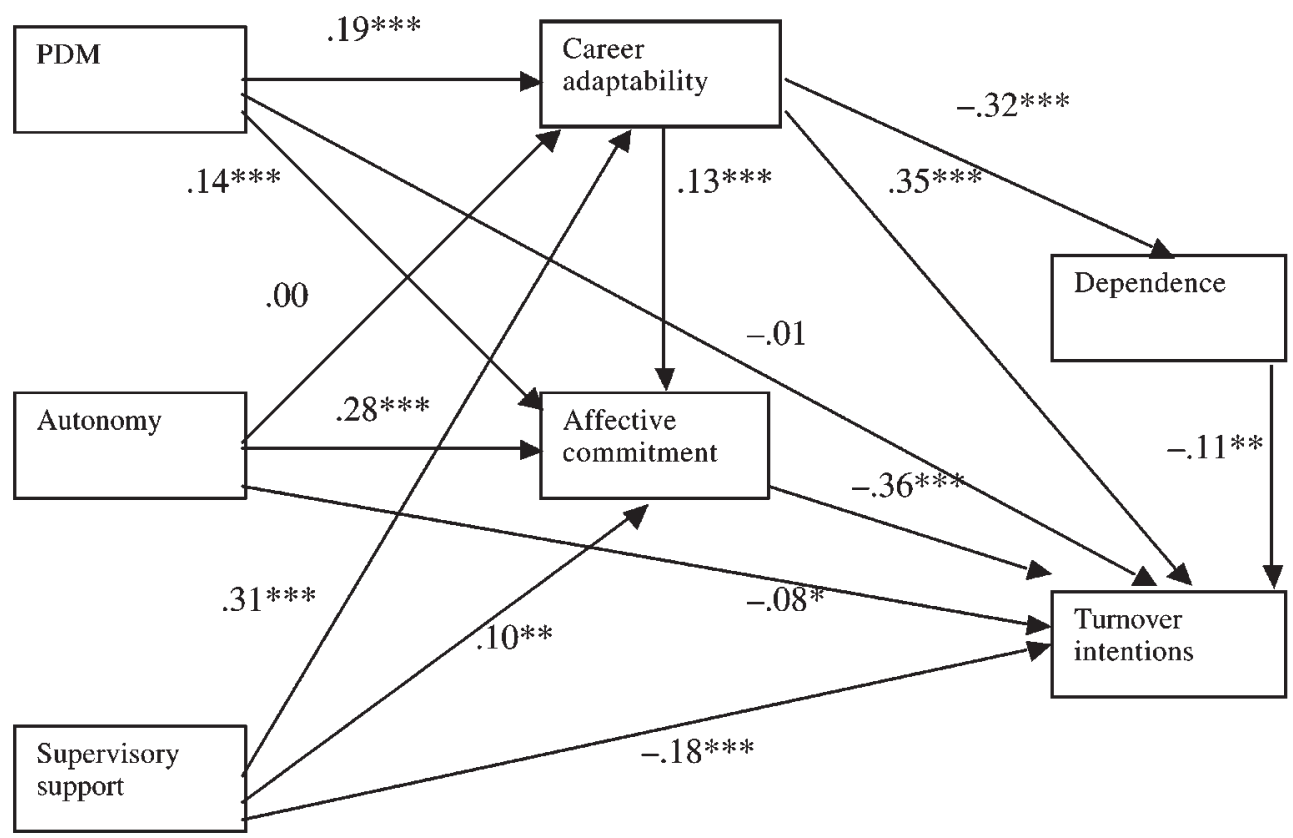

$* p<.05, * * p<.01, * * * p<.001$.

Variance explained: career adaptability .17; affective commitment .21 ; dependence .10 ; intention to leave .26 .

Figure 2. Theoretical Model with $\beta$ Coefficients.

influence of the demographic variables, that the path model has fewer relationships accounted for in the calculations, and the adjustments for measurement error described earlier. These factors also affect the explained variance in the dependent variables.

\section{Discussion and Conclusions}

The hypothesis that affective commitment and the dependence are negatively associated with turnover intentions was supported in this study. Consistent with existing research, this study found that the latter relationship was weaker than the former. Although the dependence measure suffered from low reliability, there are other reasons for its relatively weak relationship with one's intention to leave. Some employees may view dependence as a disadvantage in times of change and, consequently, accept the costs of a career search despite their lower perceived likelihood of success than their more mobile colleagues.
Career adaptability played a central role and, indeed, served as a two-edged sword. On the one hand, it enhanced affective commitment, but on the other hand it increased employees' intentions to leave, both directly and indirectly, through its link with dependence. PDM, autonomy, and supervisory support of the career were all positively related to affective commitment, consistent with prior research. Although PDM and supervisory support of the career were positively associated with career adaptability, autonomy did not predict career adaptability. Finally, only supervisory career support was associated with the intention to leave.

These findings pose interesting patterns of cause and effect with implications for managerial and human resource management policies. First, managerial practices such as PDM, encouraging autonomy, and supervisory career support enhance affective commitment, which in turn is negatively associated with turnover intentions. Moreover, career support also has a direct negative 
TABLE III Regression Including Selected Demographic Variables

Dependent variable

Demographic variables

Service in government

Education

Sex

Age

Income

Number supervised

Affective commitment

Dependence

Career adaptability

PDM

Autonomy

Supervisory support

Total R square

Adjusted R square

Total variance due to

demographic variables

(added first)
Affective commitment

R. Coeff.

$-.07$

$-.11^{*}$

$-.01$

.03

$-.14^{* *}$

$.12^{* *}$

$-.01$

$-.33^{* * *}$

$-.12^{* * *}$

$.24^{* * *}$

.02

$-.10^{* *}$

$-.15^{* * *}$

$\mathrm{F}(12,582)=14.9^{* * *}$

.24

.22

.04

.02

$.12^{* * *}$

$.14^{* * *}$

$.28^{* * *}$

$.10^{* *}$

.24

.22

.06
Career adaptability

R.Coeff.

$-.10 *$

$.13^{* *}$

$.11^{* *}$

$-.01$

.06

$.11^{*}$

$\mathrm{F}(11,583)=16.24^{* * *}$
$.11^{* *}$

$-.01$

$.25^{* * *}$

$\mathrm{F}(9,585)=12.19^{* * *}$

.16

.15

.08

${ }^{*} \mathrm{p}<.05,{ }^{* *} \mathrm{p}<.01,{ }^{* * *} \mathrm{p}<.001$.

Note: Variables in the model (excluding the demographics) that show a significant relationship with the dependent variable also showed an incrementally significant $\mathrm{R}$ square change in the stepwise regression. Sex was score $1=$ male, $2=$ female.

influence on turnover intentions. However, these practices also support career adaptability, which is weakly associated with affective commitment but strongly related to turnover intentions. That is, these managerial practices also may increase the risk that employees will leave. Although these effects may cancel each other out, the finding suggests that organizations may need to do more to garner affective commitment from employees. Indeed, efforts to involve employees may need to be combined with other practices that enhance affective commitment to reduce the likelihood that valued employees will choose to leave. Overall, the findings support those who advocate the development of affective commitment through organization-specific benefits that are difficult to replicate in other organizations (e.g., enhancing continuance commitment based on friendship networks; Cappelli, 1999).

Although it is somewhat counterintuitive to invest in employee development while recognizing that many employees may leave the organization, this may be the price organiza- tions pay in exchange for an internally flexible workforce (Waterman et al., 1994). Many mobile individuals face a choice between an uncertain yet promising future within the firm and specific job opportunities in other organizations. Therefore, reducing risk by increasing information and advice will make the organization a more attractive place to work vis-à-vis other firms. Our reasoning that supervisory career support would increase confidence in recouping investments in KSAs and, therefore, negatively associate with the intention to leave is consistent with the results. More generally, the development of mechanisms for providing advice and resources for guiding employees on their investments in KSAs to be consistent with organizational strategies may help retain valued employees. On the other hand, many organizations have chosen to place the responsibility for self-development and resources (e.g., tuition) on employees, therefore increasing career adaptability without increasing (or possibly decreasing) commitment. This approach, perhaps occasioned by 
the possibility that people will leave, exacerbates the problem. Further research into these lines of reasoning may prove fruitful in understanding the relationships between employee risk and voluntary turnover.

There are several limitations to this study. The study was cross-sectional in nature and, as such, did not establish cause-effect linkages. The study also took place in the public sector, and, though recent organizational changes have made public-sector jobs less secure, the findings may not be generalizable to the private sector, where jobs may be even less secure and both voluntary and involuntary turnover may be higher. Our model did not consider the potential effects of moderating variables. In this context, Trevor (2001) found that mobility factors (cognitive tests, education, and occupational knowledge) moderated the relationships between unemployment rates and turnover, as well as between job dissatisfaction and turnover. One promising stream of research is to consider the role of knowledge frameworks, such as complexity of work and organizationally specific knowledge, in predicting the levels of intra-organizational employability and employability across organizations (e.g., Lepak \& Snell, 1999). That is, do models relating variables to commitment and turnover intentions apply to all sectors of a knowledge typology or does it depend on the types of knowledge they use in their jobs? Finally, we believe that longitudinal research is needed to test the relationships developed in this article.

This article has found that managing commitment and voluntary turnover is a more complex process than usually discussed, since practices consistent with high involvement and learning organizations also may occasion voluntary turnover. In today's environment, characterized by competition and technological change, market mechanisms play an important, and perhaps growing, part in maintaining workforce flexibility. Yet, organizations may need to seek balance in the buy-versus-make decision-that is, be judicious in using layoffs and hiring to adapt to change. However, when downsizing decisions are inevitable, procedural justice is critical to maintaining the loyalty of the survivors and, to the extent possible, ensuring the goodwill of those who have been laid off (Brockner, 1992). In particular, high involvement practices and supervisory support serve to support policies that positively impact upon commitment and therefore limit voluntary turnover. However, they may not only fail to substitute for policies that decrease commitment, but also exacerbate the voluntary turnover.

JАск K. Iто (PhD, Washington) is a professor in the Faculty of Administration, University of Regina. His current research interests are in the fields of job insecurity and stress, changing human resource practices associated with restructuring, and career mobility.

Céleste M. Brotheridge (PhD, Manitoba), formerly at the University of Regina, is a professor with the École des sciences de la gestion (Département d'organisation et ressources humaines) at the Université du Québec à Montréal. She is particularly interested in employees' experience of the workplace, with a focus on emotions, bullying, and burnout in the workplace.

\section{REFERENCES}

Adams, J. S. (1963). Toward an understanding of inequity. Journal of Abnormal and Social Psychology, 67, 422-436.
Adams, J. S. (1965). Inequity in social exchange. In L. Berkowitz (Ed.), Advances in experimental social psychology (Vol. 2, pp. 267-299). New York: Academic Press.

Allen, N. J., \& Meyer, J. P. (1996). Affective, con- 
tinuance, and normative commitment to the organization. Journal of Vocational Behavior, 49, 252-276.

Arbuckle, J. L., \& Wothke, W. (1999). Amos 4.0 user's guide. Chicago: SmallWaters Corp.

Arthur, M. B. (1988). Career development and participation at work: Time for mating? Human Resource Management, 27, 181-199.

Arthur, M. B. (1994). The boundaryless career: A new perspective for organizational inquiry. Journal of Organizational Behavior, 15, 295-306.

Arthur, M. B., Claman, P. H., \& DeFillippi, R. J. (1995). Intelligent enterprise, intelligent careers. Academy of Management Executive, 9(4), $7-20$.

Bernardi, R. A. (1994). Validating research results when Cronbach's alpha is below .70: A methodological procedure. Educational and Psychological Measurement, 54, 766-775.

Brockner, J. (1992, Winter). Managing the effects of layoffs on survivors, California Management Review, 9-28.

Cappelli, P. (1999). The new deal at work. Boston: Harvard Business School Press.

Carson, K. D., Carson, P. P., \& Bedian, A. G. (1995). Development and construct validation of a career entrenchment measure. Journal of Occupational and Organizational Psychology, 68, 301-320.

Cohen, A. (1993). Organizational commitment and turnover: A meta-analysis. Academy of Management Journal, 36, 1140-1157.

Cohen, A., \& Hudecek, N. (1993). Organizational commitment-turnover relationship across occupational groups: A meta-analysis. Group and Organization Management, 18, 188-213.

Cohen, J., \& Cohen, P. (1983). Applied multiple regression/correlation analysis for the behavioral sciences (2nd ed.). Hillsdale, NJ: Erlbaum.

Cortina, J. M. (1993). What is coefficient alpha? An examination of theory and applications. Journal of Applied Psychology, 78, 98-104.

DeFillippi, R. J., \& Arthur, M. B. (1994). The boundaryless career: A competency-based perspective. Journal of Organizational Behavior, 15, 307-324.

Doeringer, P. B. (1967). Determinants of the structure of industrial type internal labor markets. Industrial and Labor Relations Review, 20, 206-220.

Eisenberger, R., Huntington, R., Hutchison, S., \& Sowa, D. (1986). Perceived organizational sup- port. Journal of Applied Psychology, 71, 500-507.

Ellig, B. R. (1998). Employment and employability: Foundations of the new social contract. Human Resource Management, 37, 173-175.

Feldman, D. C. (1996). Managing careers in downsizing firms. Human Resource Management, 35, 145-161.

Fried, Y., Tiegs, R. B., Naughton, T. J., \& Ashforth, B. E. (1996). Managers' reactions to a corporate acquisition: A test of an integrative model. Journal of Organizational Behavior, 17, 401-427.

Frone, M. R., Russell, M., \& Cooper, M. L. (1992). Antecedents and outcomes of work-family conflict: testing a model of the work-family interface. Journal of Applied Psychology, 77, 65-78.

Frone, M. R., Yardley, J. K., \& Markel, K. S. (1997). Developing and testing an integrative model of the work-family interface. Journal of Vocational Behavior, 50, 145-167.

Hair, J. F., Anderson, R. E., Tatham, R. L., \& Black, W. C. (1995). Multivariate data analysis with readings (4th ed.). New York: Prentice-Hall.

Hall, D. T. (1996). Protean careers of the 21 st century. Academy of Management Executive, $11(1), 8-16$.

Holmbeck, G. N. (1997). Toward terminological, conceptual, and statistical clarity in the study of mediators and moderators: Examples from the child-clinical and pediatric psychology literatures. Journal of Consulting and Clinical Psychology, 65(4), 599-610.

Hom, P. W., \& Kinicki, A .J. (2001). Toward a greater understanding of how dissatisfaction drives employee turnover. Academy of Management Journal, 44, 975-987.

House, R. J., \& Mitchell, T .R. (1974, Fall). Pathgoal theory of leadership. Contemporary Business, 3, 81-98.

Ito, J. K., \& Peterson, R. B. (1986). Effects of task difficulty and interdependence on information processing systems. Academy of Management Journal, 29, 139-149.

Jaros, S. J. (1997). An assessment of Meyer and Allen's (1991 three-component model of organizational commitment and turnover intentions. Journal of Vocational Behavior, 51, 319-337.

Kanter, R. M. (1977). Men and women of the corporation. New York: Basic Books.

Karasek, R. A. (1979). Job demands, job decision latitude, and mental stress: Implications for job 
design. Administrative Science Quarterly, 24, 285-307.

Kenny, D. A. (1979). Correlation and causation. New York: Wiley.

Latack, J. C., Kinicki, A. J., \& Prussia, G. E. (1995). An integrative process model of coping with job loss. Academy of Management Review, 20, 311-342.

Lawler, E. E., III. (1986). High-involvement management. San Francisco: Jossey-Bass.

Lee, T. W., \& Mitchell, T. R. (1994). An alternative approach: The unfolding model of employee turnover. Academy of Management Review, 19, 51-89.

Lee, T. W., Mitchell, T. R., Wise, L., \& Fireman, S. (1996). An unfolding model of voluntary turnover. Academy of Management Journal, 39, $5-36$.

Lee, T. W., \& Mowday, R. T. (1987). Voluntarily leaving an organization: An empirical investigation of Steers' and Mowday's model of turnover. Academy of Management Journal, 30, $721-743$.

Lepak, D. P., \& Snell, S. A. (1999). The human resource architecture: Toward a theory of human capital allocation and development. Academy of Management Review, 24, 31-48.

London, M. (1983). Toward a theory of career motivation. Academy of Management Review, 8, 620-630.

London, M. (1993). Relationships between career motivation, empowerment, and support for career development. Journal of Occupational and Organizational Psychology, 66, 55-69.

London, M., \& Smither, J. W. (1999). Empowered self-development and continuous learning. Human Resource Management, 38, 3-15.

Mathieu, J. E., \& Zajac, D. M. (1990). A review and meta-analysis of the antecedents, correlates, and consequences of organizational commitment. Psychological Bulletin, 108, 171-194.

McGee, G. W. \& Ford, R. C. (1987). Two (or more?) dimensions of organizational commitment: Reexamination of the affective and continuance commitment scales. Journal of Applied Psychology, 72, 638-642.

McKendall, M. A., \& Margulis, S. T. (1995, November-December). People and their organizations: Rethinking the assumptions. Business Horizons, pp. 21-28.

Meyer, J. P., \& Allen, N. J. (1984). Testing the "side bet" of organizational commitment: Some methodological considerations. Journal of Applied Psychology, 69, 372-378.

Meyer, J. P., Allen, J., \& Smith, C. A. (1993). Commitment to organizations and occupations: Extension and test of a three-component conceptualization. Journal of Applied Psychology, 78, 538-551.

Meyer, J. P., Stanley, D. J., Herscovitch, L., \& Topolnytsky, L. (2002). Affective, continuance, and normative commitment to the organization: A meta-analysis of antecedents, correlates, and consequences. Journal of Vocational Behavior, $61,20-52$.

Mowday, R. T., Steers, R. M., \& Porter, L. W. (1979). The measurement of organizational commitment. Journal of Vocational Behavior, 14, 224-247.

Netemeyer, R. G., Johnston, M. W., \& Burton, S. (1990). Analysis of role conflict and role ambiguity in a structural equations framework. Journal of Applied Psychology, 84, 925-939.

Noe, R. A., Noe, A. W., \& Bachhuber, J. A. (1990). Correlates of career motivation. Journal of Vocational Behavior, 37, 340-356.

Pfeffer, J. (1998). The human equation: Building profits by putting people first. Cambridge, MA: Harvard Business School Press.

Reichel, A., \& Neumann, Y. (1993). Work stress, job burnout, and work outcomes in a turbulent environment. International Studies of Management \& Organization, 23(3), 75-96.

Roehling, M. V., Cavanaugh, M. A., Moynihan, L. M., \& Boswell, W. R. (2000). The nature of the new employment relationship: A content analysis of the practitioner and academic literatures. Human Resource Management, 39, 305-320.

Stroh, L. K., Brett, J. M., \& Reilly, A. (1994). A decade of change: managers' attachment to their organizations and their jobs. Human Resource Management, 33, 531-548.

Sullivan, S. E. (1999). The changing nature of careers: A review and research agenda. Journal of Management, 25, 457-484.

Trevor, C. O. (2001). Interactions among actual ease of movement determinants and job satisfaction in the prediction of voluntary turnover. Academy of Management Journal, 44, 621-638.

Tsui, A. S., Pearce, J. L., Porter, L. W., \& Hite, J. P. (1995). Choice of employee-organization relationship. In K. M. Rowland \& G. R. Ferris (Eds.), Research in personnel and human re- 
source management, (Vol. 13, pp. 113-151), Greenwich, CT: JAI Press.

Waterman, R. H. Jr., Waterman, J. A., \& Collard, B. A. (1994). Toward a career resilient workforce. Harvard Business Review, 72(4), 87-95.

Wayne, S. J., Shore, L. M., \& Liden, R. C. (1997). Perceived organizational support and leader-member exchange: A social exchange perspective. Academy of Management Journal, 40, 82-111.

Weick, K. E., \& Berlinger, L .R. (1989). Career improvisation in self-designing organizations. In M. B. Arthur, D. T. Hall, \& B. S. Lawrence
(Eds.), Handbook of career theory (pp. 313-328). Cambridge, UK: Cambridge University Press.

Whitener, E. M., \& Walz, P. M. (1993). Exchange theory determinants of affective and continuance commitment and turnover. Journal of Vocational Behavior, 42, 265-281.

Williams, L. J., \& Hazer, J. T. (1986). Antecedents and consequences of satisfaction and commitment in turnover models: A reanalysis using latent variable structural equation methods. Journal of Applied Psychology, 71, 219-231. 